HORTSCIENCE 27 (11): 1222-1223. 1992.

\title{
Micropropagation of Lupinus texensis from Cotyledonary Node Explants
}

\author{
Abba Upadhyaya ${ }^{1}$, Tim D. Davis ${ }^{2}$, Daksha Sankhla, and N. Sankhla \\ Texas Agricultural Experiment Station, Texas A\&M University Research \\ and Extension Center, 17360 Coit Road, Dallas, TX 75252-6599
}

Additional index words. auxins, cytokinins, rooting, Texas bluebonnet, tissue culture

Abstract. Both kinetin and BA promoted in vitro shoot formation from hypocotyl explants of Lupinus texensis Hook. placed on Murashige and Skoog (MS) medium. With either cytokinin, shoot formation was best at $\approx 4.5 \mu \mathrm{M}$. Adventitious root formation was observed only on tissue culture-derived shoots placed in MS media containing 5.4 to $54 \mu \mathrm{M}$ NAA. IAA and IBA, at concentrations ranging from 5 to $55 \mu \mathrm{M}$, failed to stimulate rooting. Even at the optimal concentration of NAA, only $14 \%$ of the shoots produced roots. Thus, although hypocotyl explants readily produced shoots, adventitious root formation on these shoots occurred with relatively low frequency. Chemical names used: 6-benzylaminopnrine (BA); indole-3-acetic acid (IAA); indole-3butyric acid (IBA); 6-furfurylaminopurine (kinetin); 1-naphthaleneacetic acid (NAA).

Lupinus texensis (Texas bluebonnet) is an attractive spring-flowering leguminous annual that has potential as a low-maintenance bedding plant or for use in roadside plantings. This species is adapted to a variety of environmental conditions and has been grown successfully in many parts of the world (Andrews, 1986). Thus, there is considerable interest in the commercial development of this species as an ornamental (Davis et al., 1991).

Recent advances in plant biotechnology have opened new avenues for the develop-

Received for publication 16 Mar. 1992. Accepted for publication 17 June 1992. The cost of publishing this paper was defrayed in part by the payment of page charges. Under postal regulations, this paper therefore must be hereby marked $a d$ vertisement solely to indicate this fact.

${ }^{1}$ Current address: U.S. Dept. of Agriculture, Agricultural Research Service, Climate Stress Lab: BARC-W, Bldg. 001, Beltsville, MD 20705.

${ }^{2}$ To whom reprint requests should be addressed. ment of ornamentals with novel characteristics (Mol et al., 1989). For instance, antisense RNA technology and chalcone synthase gene constructs have been used to alter flower pigmentation (van der Krol et al., 1990). Such constructs could be valuable in creating new flower colors in L. texenis. As a prerequisite for establishing a gene transfer system for this plant, we initiated studies aimed at developing a micropropagation protocol. For other leguminous species, cotyledonary nodes have been useful for the production of transgenic plants (Chee et al., 1989; Jackson and Hobbs, 1990). We found no information in the literature pertaining to the in vitro culture of L. texensis. Sator (1985), however, attempted to regenerate plants from several other Lupinus spp. (L. polyphyllus, L. hartwegii, L. angustifolius, and L. luteus) but only obtained limited shoot formation. The present report describes in vitro shoot and root formation in L. terensis. 
Table 1. Effect of kinetin and BA on in vitro shoot count and length of Lupinus ferensis after 4 weeks.

\begin{tabular}{|c|c|c|c|}
\hline $\begin{array}{l}\text { Growth } \\
\text { regulator }\end{array}$ & $\begin{array}{c}\text { Concn } \\
(\mu \mathrm{M})\end{array}$ & $\begin{array}{l}\text { Mean shoot } \\
\text { no./explant }\end{array}$ & $\begin{array}{l}\text { Mean shoot } \\
\text { length (mm) }\end{array}$ \\
\hline \multicolumn{2}{|c|}{$\begin{array}{l}\text { Control (MS basal } \\
\text { medium) }\end{array}$} & $4.3 \pm 0.6^{2}$ & $60 \pm 2$ \\
\hline \multirow[t]{5}{*}{ Kinetin } & 0.5 & $4.5 \pm 0.5$ & $54 \pm 3$ \\
\hline & 4.6 & $10.8 \pm 0.7$ & $48 \pm 1$ \\
\hline & 13.3 & $8.6 \pm 0.9$ & $35 \pm 1$ \\
\hline & 23.2 & $7.2 \pm 1.2$ & $25 \pm 1$ \\
\hline & 46.0 & $6.2 \pm 0.8$ & $8 \pm 1$ \\
\hline \multirow[t]{5}{*}{$\mathrm{BA}$} & 0.4 & $9.5 \pm 1.2$ & $58 \pm 2$ \\
\hline & 4.4 & $15.0 \pm 0.5$ & $52 \pm 1$ \\
\hline & 13.9 & $13.4 \pm 1.1$ & $40 \pm 1$ \\
\hline & 22.2 & $9.0 \pm 1.1$ & $30 \pm 1$ \\
\hline & 44.0 & $9.7 \pm 0.8$ & $15 \pm 1$ \\
\hline
\end{tabular}

${ }^{z} \pm$ Values indicate SE of the mean $(n \geq 60)$ regression analyses indicated shoot count response to either kinetin or BA was cubic and significant at $P=0.05$; regression analysis indicated shoot length response to either kinetin or BA was quadratic and significant at $P=0.05$.

Table 2. Effect of NAA on in vitro rooting of tissue culture-derived shoots of Lupinus texensis. Data obtained 28 days after placement of 3-week-old shoots (developed on MS medium containing $4.4 \mu \mathrm{M}$ BA) in rooting medium.

\begin{tabular}{lcc}
\hline $\begin{array}{l}\text { NAA concn } \\
(\mu \mathrm{M})\end{array}$ & $\begin{array}{c}\text { Microcuttings roots/rooted } \\
\text { rooted }(\%)\end{array}$ & $\begin{array}{c}\text { Mean no. } \\
\text { explant }\end{array}$ \\
\hline 0 (basal MS & & \\
medium) & 0 & $\cdots$ \\
5 & $4.8 \pm 3.0^{\mathrm{z}}$ & $13 \pm 2$ \\
27 & $14.0 \pm 1.1$ & $24 \pm 2$ \\
54 & $10.0 \pm 0.5$ & $18 \pm 1$ \\
Significance $^{y}$ & Quadratic & Cubic \\
\hline
\end{tabular}

${ }^{\mathrm{z}} \pm$ Values indicate SE of the mean.

${ }^{y} P=0.05$ determined by regression analysis.

Seeds were scarified in concentrated sulfuric acid for 35 to $40 \mathrm{~min}$ (Davis et al., 1991) and rinsed with distilled water. Following scarification, the seeds were dipped in $70 \%$ ethanol for $30 \mathrm{sec}$ and then rinsed four to five times with distilled water. Thereafter, the seeds were treated with $5.25 \%$ sodium hypochlorite for $15 \mathrm{~min}$ and $0.2 \% \mathrm{HgCl}_{2}$ for $5 \mathrm{~min}$. After being rinsed with sterile distilled water, seeds were placed on basal MS medium adjusted to $\mathrm{pH} 5.8$ (Murashige and Skoog, 1962). Seedlings were cultured in cylindrical glass culture vessels $(50-\mathrm{ml}$ capacity) at $25 \pm 1 \mathrm{C}$ under a 16 -h photoperiod and a photosynthetic photon flux of 40 to 50 $\mu \mathrm{mol} \cdot \mathrm{m}^{-2} \cdot \mathrm{s}^{-1}$ provided by cool-white fluorescent lamps. All subsequent experiments were conducted under these conditions.

Explants containing the cotyledonary node (10 $\pm 1 \mathrm{~mm}$ long with cotyledons removed) from 8- to 12-day-old seedlings (first true leaf just becoming visible at the apex) were placed on MS medium supplemented with various concentrations of kinetin or BA. One explant was used per culture vessel. The number of shoots per culture and shoot lengths were determined after 4 weeks. For the rooting experiments, 3- to 4-week-old microshoots $(50 \pm 5 \mathrm{~mm}$ long $)$ that developed on the medium containing $4.4 \mu \mathrm{M}$ BA were placed on basal MS medium supplemented with various concentrations of IAA, IBA, or NAA. The percentage of microcuttings exhibiting adventitious roots and the number of roots per culture were determined after 28 days. There was a minimum of 20 cultures per treatment and each experiment was repeated at least three times.

Kinetin $(\geq 4.6 \mu \mathrm{M})$ and BA (at all concentrations used) increased the number of shoots formed at the cotyledonary node ( $\mathrm{Ta}-$ ble 1). For both cytokinins, shoot formation was greatest at $\approx 4.5 \mu \mathrm{M}$. With $\mathrm{BA}$, this concentration resulted in $\approx 15$ shoots per explant after 4 weeks. With kinetin or BA $>4.5$ $\mu \mathrm{M}$, shoot formation declined but was still higher than in the control. Both cytokinins inhibited shoot growth, with severe stunting occurring at the higher concentrations.

Adventitious root formation was only observed on shoots placed in culture media containing NAA (Table 2). Both IAA and IBA, at concentrations ranging from 5 to 54 $\mu \mathrm{M}$, failed to induce rooting (data not shown). The highest rooting percentage $(14 \%)$ and the most roots (24) were produced in the medium containing $27 \mu \mathrm{M}$ NAA. Compared with most other herbaceous species, $L$. texensis appears to be difficult to root. Adventitious root formation has been observed from apical stem cuttings of $L$. albus and L. hartwegii (Ball, 1946; Lee, 1955), but Sator (1985) had little success in rooting in vitro- regenerated shoots of $L$. hartwegii and $\boldsymbol{L}$. luteus.

The results of this study indicate that shoot formation from cotyledonary node explants of $L$. texensis occurs readily on MS medium supplemented with cytokinins. Adventitious root formation on the microshoots, however, occurs only in the presence of relatively high concentrations of NAA and even then only at low frequency. About half of our rooted plantlets survived transfer to ex vitro conditions. More research is needed to overcome the recalcitrant nature of $L$. texensis shoots with regard to rooting and to improve acclimatization so that a higher frequency of plantlet regeneration can be achieved.

\section{Literature Cited}

Andrews, J. 1986. The Texas bluebonnet. Univ. Texas Press, Austin.

Ball, E. 1946. Development in sterile culture of stem tips and subjacent regions of Tropaeolum majus L. and Lupinus albus L. Amer. J. Bot. 33:301-318.

Chee, P.P., K.A. Fober, and J.L. Slightom. 1989. Transformation of soybean (Glycine max) by infecting germinating seeds with Agrobacterium tumefaciens. Plant Physiol. 91:1212-1218.

Davis, T.D., S.W. George, A. Upadhyaya, and J. Parsons. 1991. Improvement of seedling emergence in Lupinus texensis Hook. following seed scarification treatments. J. Environ. Hort. 9:17-21.

Jackson, J.A. and S.L.A. Hobbs. 1990. Rapid shoot production from cotyledonary node explants of pea. In Vitro Cell Dev. Biol. 26:835838.

Lee, A.E. 1955. Growth in culture of excised portion of lupin embryos. Bot. Gaz. 116: 354-364.

Mol, J.N.M., A.R. Stuitje, A. Gerats, A.R. van der Krol, and R. Jorgenson. 1989. Saying it with genes! Molecular flower breeding. Trends Biotechnol. 7:148-153.

Murashige, T. and F. Skoog. 1962. A revised medium for rapid growth and bioassays with tobacco tissue cultures. Physiol. Plant. 15:473497.

Sator, C. 1985. Studies on shoot regeneration of lupins (Lupinus spp.) Plant Cell Rptr. 4:126128.

van der Krol, A.R., L.A. Mur, P.D. Lange, J.N.M. Mol, and A.R. Stuitje. 1990. Inhibition of flower pigmentation by antisense CHS gene: Promoter and minimal sequence requirement for antisense effect. Plant Mol. Biol. 14:457-466. 